\title{
From Interlaken to Copenhagen: What Has Become of the Proposals Aiming to Reform the Functioning of the European Court of Human Rights?
}

\author{
Lize R. Glas*
}

\begin{abstract}
The States Parties to the European Convention on Human Rights have adopted five declarations on the future of the European Court of Human Rights since 2010. These declarations identified problems surrounding the Convention system and proposed reform measures. This article examines what has become of the proposals aiming to reform the Court's functioning, which will lead to insight into the problems surrounding the system, the type of solutions proposed and whether the declarations have led to change. The article also discusses the background to the conferences and characterises the focus of each declaration. The conclusion is that most proposals have not been implemented, mainly due to principled or practical opposition of the Court, and that the implemented proposals have not led to profound change. The influence of the declarations should not be overstated therefore, although they can be of political significance by offering support to or criticising the Court.
\end{abstract}

KEYWORDS: European Court of Human Rights, reform, high-level conferences

\section{INTRODUCTION}

A new tradition of organising high-level conferences on the future of the European Court of Human Rights ('the Court' or ECtHR) began with the organisation of the Interlaken Conference on 18 and 19 February 2010. So far, five such conferences have taken place. ${ }^{1}$ Each conference led to the adoption of a declaration in which the States Parties to the European Convention on Human Rights ('the Convention' or ECHR) ${ }^{2}$ took stock of the reform process that commenced in Interlaken. Additionally, the States

* Assistant Professor of European Law, Radboud University Nijmegen, Nijmegen, The Netherlands (1.glas@jur.ru.nl).

1 Izmir Conference, 26-27 April 2011; Brighton Conference, 18-20 April 2012; Brussels Conference 26-27 March 2015; Copenhagen Conference 12-13 April 2018. See also the Oslo Conference on the long-term future of the Court, 7-8 April 2014 and Section 2 infra.

2 1950, ETS 5. 
identified the problems surrounding the Convention system and proposed reform measures in the declarations.

The form of the reform debate may have changed with the declarations, but the Interlaken Conference was certainly not the first occasion where the reform of the Convention system was debated. ${ }^{3}$ The 'tradition' of reforming the system had begun right after the adoption of the Convention in 1950, when negotiations for Protocol 1 to the Convention started. ${ }^{4}$ Besides this and other optional protocols that created new rights, the Convention system significantly changed when Protocol 11 entered into force in 1998, abolishing the European Commission on Human Rights and establishing a fulltime court. Protocol 14 to the ECHR brought some other major changes, introducing, inter alia, the single judge formation and the significant disadvantage admissibility criterion. ${ }^{5}$ This is where the reform process had left off when the States gathered in Interlaken. ${ }^{6}$

In this article, I would like to contribute to yet another tradition: of this journal in providing commentary on the reform of the Convention system. ${ }^{7}$ More precisely, in this article I examine what has become of the proposals of the States in the five declarations to reform the functioning of the Court. This examination will establish whether the declarations have led to actual change and, if so, the type of reform that has occurred. It is proposed that the reform measures be placed in one of two categories. ${ }^{8}$ First, measures that change how the Convention system functions. ${ }^{9}$ Such measures 'may be sweeping in the sense that the functioning is profoundly changed, but are not revolutionary because they leave unchallenged the overarching object and purpose of [the] system and its general principles. ${ }^{10}$ In the second category fall revolutionary measures that change the object and purpose of the system and its general principles. ${ }^{11}$ Measures dictating that

3 See elaborately Bates, The Evolution of the European Convention on Human Rights. From Its Inception to the Creation of a Permanent Court of Human Rights (2010).

4 Schabas, The European Convention on Human Rights. A Commentary (2015) at 955-6.

5 Two important reports concerning reform and preceding Protocol 14 of the ECHR are Lord Woolf, Review of the Working Methods of the European Court of Human Rights, \#1545044 (December 2005), available at: www.echr.coe.int [last accessed 19 December 2019]; Ministers' Deputies, Report of the Group of Wise Persons submitted to the Committee of Ministers, CM(2006)203, 15 November 2006, available at: search.coe.int [last accessed 19 December 2019].

6 Although Protocol 14 of the ECHR was adopted years before the Interlaken Conference took place, it entered into force only some months after the conference (1 June 2010).

7 See, for example, Mowbray, 'Crisis Measures of Institutional Reform for the European Court of Human Rights' (2009) 9 Human Rights Law Review 647; Mowbray, 'The Interlaken Declaration: The Beginning of a New Era for the European Court of Human Rights?' (2010) 10 Human Rights Law Review 519; Greer and Wildhaber, 'Revisiting the Debate about 'constitutionalising' the European Court of Human Rights' (2013) 12 Human Rights Law Review 655; Glas, 'Changes in the Procedural Practice of the European Court of Human Rights: Consequences for the Convention System and Lessons to be Drawn' (2014) 14 Human Rights Law Review 671; de Londras and Dzehtsiarou, 'Managing Judicial Innovation in the European Court of Human Rights' (2015) 15 Human Rights Law Review 523; Shelton, 'Significantly Disadvantaged? Shrinking Access to the European Court of Human Rights' (2016) 16 Human Rights Law Review 303; Spano, 'The Future of the European Court of Human Rights: Subsidiarity, Process-Based Review and the Rule of Law' (2018) 18 Human Rights Law Review 473.

8 Glas, The Theory, Potential and Practice of Procedural Dialogue in the European Convention on Human Rights System (2016) at 55-6.

9 Ibid.

10 Ibid.

11 Ibid. 
the Court delivers only constitutional justice and not individual justice also fall in the second category. ${ }^{12}$ Additionally, the examination will give insights into the problems confronting the Convention system over the past few years and the type of solutions that the States Parties have proposed.

This article is different from others dealing with the reform process because it not only discusses what was proposed, but also whether these proposals have been implemented. Moreover, it is based not just on one reform measure or one declaration, but on all five declarations, which makes it possible to discuss many different proposals and to draw conclusions on the type of proposals which have been made and which have been implemented.

The reason for conducting this examination now is that the Interlaken Declaration instructed the Committee of Ministers to decide before the end of 2019 on whether Protocol 14 to the ECHR and the measures in the Action Plan of the Interlaken Declaration 'have proven to be sufficient to assure sustainable functioning of the control mechanism of the Convention or whether more profound changes are necessary.' ${ }^{13}$ This article does not aim to duplicate the assessment that the Committee of Ministers needs to make. Nevertheless, it gives insight into the changes that have been implemented, into the solutions that the States have been prepared to accept and into whether the States may be willing to accept any profound changes if they turn out to be necessary.

To ensure the feasibility of examining in a single article what has become of the proposals in the five declarations, this article only considers those proposals that are somewhat specific. ${ }^{14}$ Furthermore, it only relies on new proposals or those which encourage the Court to further develop a certain practice. Therefore, it does not take into account the proposals which only encourage the Court to continue to pursue a certain practice. ${ }^{15}$ As a consequence of focusing exclusively on proposals concerning the Court's functioning, the article does not study proposals aiming to improve the implementation of the Convention by the States, ${ }^{16}$ the execution of the Court's

12 See, for a description of the debate about this measure, Gerards and Glas, 'Access to Justice in the European Convention on Human Rights System' (2017) 35 Netherlands Quarterly of Human Rights 11 at 17-8.

13 High-Level Conference on the Future of the European Court of Human Rights, 19 February 2010, ('Interlaken Declaration'), Implementation at para 6. See also Copenhagen Declaration on the reform of the European Convention on Human Rights system, 13 April 2018, ('Copenhagen Declaration') at para 54. When last reviewing this article (on 19 December 2019), the Committee of Ministers had not yet published its decision, although one of the agenda items of the 1363rd meeting of the Ministers' Deputies was a report 'Contribution to the evaluation foreseen by the Interlaken Declaration. The CDDH had adopted its Contribution of the $\mathrm{CDDH}$ to the evaluation provided for by the Interlaken Declaration, $\mathrm{CDDH}$ (2019)R92Addendum2 on 29 November 2019. The CDDH concluded (at para 221) that ' $\mathrm{t}$ ] he necessity of a new major revision of the system is ... not apparent'; 'the current challenges the Convention system is facing can be met within the existing framework'. The CDDH added that ' $[\mathrm{w}]$ hat appears important is rather to allow the Convention system as it has emerged from the Interlaken process and Protocol No. 14, provided with sufficient resources which the States Parties have committed themselves to provide, to demonstrate fully its potential.'

14 Not broadly formulated proposals such as 'encourages open dialogues between the Court and the States Parties': see High Level Conference on the Future of the European Court of Human Rights, 20 April 2012; ('Brighton Declaration') at para 12(c).

15 For example, continuing to identify structural problems: see Interlaken Declaration, Action Plan at para 10(b).

16 See CDDH, Report on measures taken by the member States to implement relevant parts of the Interlaken and Izmir Declarations, CDDH(2012)R76 Addendum I, 30 November 2012. 
judgments as supervised by the Committee of Ministers or the selection process of the Court's judges and their terms of office.

Before examining the proposals and what has become of them in Section 3, this article will first introduce the five conferences and the declarations in Section 2. Section 2 will sketch the background to the conferences and characterise the focus of each declaration. Based on the examination of the separate proposals in Section 3, Section 4 will discuss the proposals that have not been implemented separately from the proposals that have been implemented. Thereafter, conclusions will be drawn.

\section{INTRODUCTION TO THE CONFERENCES AND THE DECLARATIONS}

This Section sketches, in general terms, the background against which the conferences took place (Section 2.A). This will allow for better understanding of the focus of each declaration a topic discussed in this section as well (Section 2.B). Focusing on the declarations in turn facilitates understanding why certain more specific proposals were made in them. These proposals are analysed in Section 3.

\section{A. Background to the Conferences}

The series of conferences were in response to a call by President Costa for the States Parties to organise a conference to 'reflect on how to protect' the Convention rights, rethink 'practical aspects' and give the Court a 'clarified mandate. ${ }^{17}$ President Costa also sought to 'express support for the Court' ${ }^{18}$ and hoped that the conference would 'leave its mark ... on the political level. ${ }^{19}$ Switzerland responded to this call in its capacity as Chair of the Committee of Ministers and organised the Interlaken Conference. This conference and the other conferences were very formal occasions; the actual work of negotiating the declarations was done in the weeks prior to the conferences. ${ }^{20}$ Usually, a draft of the declaration was published so that not only the States but also the Court, the Steering Committee for Human Rights $(\mathrm{CDDH}),{ }^{21}$ non-governmental organisations and academics could, and did, provide input. ${ }^{22}$

The shared background against which the five conferences took place is the Court's caseload crisis and causes include the failure of the States Parties to fully implement

17 Costa, 'Speech' (Opening of the judicial year, Strasbourg, 30 January 2009), at 69, available at: www.echr. coe.int [last accessed 19 December 2019].

18 Ibid. at 70. See also Mowbray, 'Subsidiarity and the European Convention on Human Rights' (2015) 15 Human Rights Law Review 313 at 329.

19 Costa, 'Memorandum of the President of the European Court of Human Rights to the States with a View to Preparing for the Interlaken Conference', 3 July 2009, at 3, available at: www.echr.coe.int [last accessed 19 December 2019].

20 Milner, 'Protocols no. 15 and 16 to the European Convention on Human Rights in the context of the perennial process of reform: a long and winding road' (2014) 17 Zeitschrift für Europarechtliche Studien 19 at 26; Gerards and Lambrecht, 'The final Copenhagen Declaration: fundamentally improved with a few remaining caveats', Strasbourg Observers, 18 April 2018, available at: strasbourgobservers.com [last accessed 19 December 2019].

21 The CDDH is composed of experts of the 47 Council of Europe Member States and 'conducts the intergovernmental work of the Council of Europe in the human rights field, advises and gives its legal expertise to the Committee of Ministers on all questions within its field of competence', see Council of Europe, 'Human Rights Protection and Development', available at: www.coe.int [last accessed 19 December 2019].

22 The draft Brighton Declaration was not published, but leaked to The Guardian newspaper, see House of Commons Library, The UK and Reform of the European Court of Human Rights, SN/IA/6277, 27 April 2012, at 15 . 
the Convention and execute the Court's judgments. A positive development has taken place in this regard since Interlaken. In the months after Interlaken, the caseload had reached its peak of 160,000 pending applications. ${ }^{23}$ By the Copenhagen Conference, this number had dropped to the still considerable, but significantly decreased, number of less than $56,000 .{ }^{24}$ Specifically, one aspect of the caseload problem-the high number of manifestly inadmissible applications - was largely solved prior to the Brussels Conference. ${ }^{25}$ However, the high number of repetitive applications has remained problematic from Interlaken to Copenhagen, ${ }^{26}$ although their number has decreased. ${ }^{27}$ Another aspect of the caseload problem that was not identified as such in the first two declarations was identified in the Brighton Declaration: the 'growing number of potentially well-founded applications. ${ }^{28}$

The caseload was not the only problem on the mind of the organising States in the cases of the Brighton and Copenhagen Conferences. Prior to the Brighton Conference, discontent with the Court and its rulings had grown in a number of different States, amongst which were the United Kingdom (UK) ${ }^{29}$ and Denmark. One of the priorities of the UK's chairmanship of the Committee of Ministers was to ensure that 'the Court plays a subsidiary role where member states are fulfilling their obligations under the Convention. ${ }^{30}$ In line with this priority, the draft Brighton Declaration contained proposals, which would decrease the Court's decision-making power and its review of state action. ${ }^{31}$ About four years later, Danish politicians aimed to reform the Convention system as well. ${ }^{32}$ They considered the Court's dynamic interpretation in the field of the deportation of foreign criminals especially problematic. ${ }^{33}$ Accordingly, the Danish chairmanship prioritised shedding 'light on how we can handle the challenge resulting from the fact that the [Court] ... increasingly has influence on policy areas of critical

Spielmann, 'La mise en œuvre de la Convention européenne des droits de l'homme, notre responsabilité partagée', Brussels Conference, 26-27 March 2015, available at: www.echr.coe.int [last accessed 19 December 2019].

24 Raimondi, 'Speech', Copenhagen Conference, 11-13 April 2018, at 2, available at: www.echr.coe.int [last accessed 219 December 2019].

25 Spielmann, supra $\mathrm{n} 23$ at 1.

26 Interlaken Declaration, Preamble at para 7; Copenhagen Declaration at para 51.

27 ECtHR, 'Contribution of the Court to the Brussels Conference', 16 January 2015, at para 12, available at: www.echr.coe.int [last accessed 19 December 2019].

28 Brighton Declaration at para 6. See also, for example, High-level Conference on the 'Implementation of the European Convention on Human Rights, our shared responsibility',27 March 2015 ('Brussels Declaration'), Preamble at para i; Copenhagen Declaration at para 44.

29 Helfer, 'The Burdens and Benefits of Brighton' (2012) 1 ESIL Reflections 1 at 1; O’Meara, 'Reforming the ECtHR: The Impacts of Protocols 15 and 16 to the ECHR' (2015) iCourts Working Paper Series 31, at 8, available at: ssrn.com/abstract=2654205 [last accessed 19 December 2019]; Madsen, 'Rebalancing European Human Rights: Has the Brighton Declaration Engendered a New Deal on Human Rights in Europe?' (2018) 9 Human Rights Law Review 119 at 200.

30 Ministers' Deputies, Priorities of the United Kingdom Chairmanship of the Committee of Ministers of the Council of Europe, CM/Inf(2011)41, 27 October 2011. See also Cameron, 'Speech on the European Court of Human Rights' (Parliamentary Assembly of the Council of Europe, 25 January 2012), available at: www.gov.uk [last accessed 19 December 2019].

31 Helfer, supra n 29 at 1; Cram, 'Protocol 15 and Articles 10 and 11 ECHR - The Partial Triumph of Political Incumbency Post Brighton?' (2018) 67 International \& Comparative Law Quarterly 477 at 478.

32 Hartmann, 'A Danish Crusade for the Reform of the European Court of Human Rights', EIJL: Talk!, Blog, 14 November 2017, available at: www.ejiltalk.org [last accessed 19 December 2019]. Ibid. 
importance to member States and their populations. ${ }^{34}$ Many commentators warned that the proposals in the draft Copenhagen Declaration 'could do [harm] to the Court's independence and authority. ${ }^{35}$

So as President Raimondi has also summarised, the Court has been confronted with two problems the over the past few years: a high number of pending cases, and a problem of a different 'political nature', by which its authority and legitimacy have been questioned. ${ }^{36}$ The next section discusses, inter alia, how these problems are reflected in the declarations.

\section{B. The Focus of the Declarations}

The declarations contain some recurring elements. These elements include affirming the States' commitment to the Convention and the Court, ${ }^{37}$ recognising the extraordinary contribution of the Court to the protection of human rights in Europe ${ }^{38}$ and acknowledging the importance of the right of individual petition as a cornerstone of the Convention system. ${ }^{39}$ Nevertheless, as this section will clarify, the declarations also each have their own focus.

The Interlaken Declaration aims 'to find a solution for the chronic [case] overload' ${ }^{40}$ so the Court can handle clearly inadmissible and repetitive applications. ${ }^{41}$ The broader aim of the Interlaken Declaration was to 'establish a roadmap for the reform process towards long-term effectiveness of the Convention system. ${ }^{42}$ However, rather than containing 'concrete plans', the Interlaken Declaration contains 'a strong political statement. ${ }^{3}$ The CDDH was instructed to study more 'specific proposals', including those requiring amending the Convention. ${ }^{44}$ Many ideas in the Interlaken Declaration had been made previously. ${ }^{45}$

Ministers Deputies, Priorities of the Danish Chairmanship of the Committee of Ministers of the Council of Europe, $\mathrm{CM} / \operatorname{Inf}(2017) 22,13$ November 2017, at 3.

35 Gerards and Lambrecht, supra n 20. See also Cram, supra $n 31$ at 483; PACE, Recommendation 2129 (2018), Copenhagen Declaration, appreciation and follow-up, 26 April 2018, at para 5.

36 Raimondi, 'Speech' (Conferral of the Treaties of Nijmegen Medal, Nijmegen, 18 November 2016), at 4, available at: www.echr.coe.int [last accessed 19 December 2019].

37 Interlaken Declaration, Preamble at para 1; High Level Conference on the Future of the European Court of Human Rights, 27 April 2011 ('Izmir Declaration'), Preamble at para 1; Brighton Declaration at para 1; Brussels Declaration, Preamble; Copenhagen Declaration at para 1.

38 Interlaken Declaration, Preamble at para 2; Izmir Declaration, Preamble at para 3; Brighton Declaration at para 2; Brussels Declaration, Preamble; Copenhagen Declaration at para 2.

39 Interlaken Declaration, The Conference at para 1 and Action Plan at para 1; Izmir Declaration, Follow-up Plan at para A(1); Brighton Declaration at paras 2, 13, 31; Brussels Declaration, Preamble; Copenhagen Declaration at paras 1, 48. See also CDDH, Opinion on the issues to be covered at the high-level Conference on the future of the European Court of Human Rights, CM(2009)181, 2 December 2009, at para 9, available at: rm. coe.int/16805cffa4 [last accessed 19 December 2019]; Costa, supra n 19 at 4; ECtHR, Preliminary opinion of the Court in preparation for the Brighton Conference, v2-\#3841140, 20 February 2012, at para 25, available at: coe.int [last accessed 19 December 2019].

40 Humanrights.ch, 'Declaration adopted at the Interlaken Conference on the Reform of the European Court of Human Rights', 19 February 2010, available at: www.humanrights.ch [last accessed 19 December 2019]. See also Interlaken Declaration, Preamble at para 9.

41 Interlaken Declaration, The Conference at para 6.

42 Interlaken Declaration, Preamble at para 10.

43 Humanrights.ch, supra $\mathrm{n} 40$.

44 Interlaken Declaration, Implementation at para 4. See also ibid. at para 5.

45 Bates, supra $n$ at 509. 
The Turkish chairmanship organised the Izmir Conference to take stock of the reform proposals that did not require amending the Convention ${ }^{46}$ and to consider 'further concrete steps.' ${ }^{47}$ The aims of the Izmir Declaration are broadly the same as those of the Interlaken Declaration ${ }^{48}$ and the former 'largely affirmed what had been agreed' in Interlaken. ${ }^{49}$ Still, the tone of the Izmir Declaration 'visibly shifted in some important aspects' compared to the Interlaken Declaration, as the States expressed concerns over, for example, the high number of interim measures requested in immigration cases. ${ }^{50}$

The final text of the Brighton Declaration turned out to be 'much less invasive on the Court's prerogatives' than its draft. ${ }^{51}$ The document still stands out, compared to the previous two declarations, because it is not limited to 'ongoing technical reform'52 that would leave the Convention system broadly intact. ${ }^{53}$ Instead, it contains provisions concerning the Court's subsidiarity role that aim to restrict the Court's scrutiny of the States' law and practice ${ }^{54}$ and that attack the quality of the Court's judges and judgments. ${ }^{55}$ The impact of such provisions should not, however, be overstated: according to the Court's President, the Brighton Declaration will not change how the Court does its job. ${ }^{56}$ This declaration also stands out because it proposes 'concrete, pragmatic steps' for the implementation of the Convention by the States. ${ }^{57}$ Furthermore, the Brighton Declaration is the only declaration to instruct the Committee of Ministers to amend the Convention. ${ }^{58}$

The question of the effective implementation of the Convention and the execution of the Court's judgments and supervision thereof was accorded 'greater prominence'

Davutoğlu, 'Opening Address', Izmir Conference, Izmir, 26 April 2011, at 10, available at: rm.coe.i $\mathrm{nt} /$ proceedings-high-level-conference-on-the-future-of-the-european-court-/1680695aaf [last accessed 19 December 2019]. See also Izmir Declaration, Preamble at para 14 and The Conference at para 1.

47 Davutoğlu, supra n 46 at 12. See also Izmir Declaration, Declaration at para 14 and Proposes, at para 1.

48 Davutoğlu, supra $n 46$ at $10-11$.

49 Greer and Wildhaber, supra $\mathrm{n} 7$ at 660.

50 Patrick, 'Building on Brighton: A foundation for the future of the European Court of Human Rights?' [2012] Justice Journal 32 at 35; Izmir Declaration, The Conference at para 12.

51 Buyse, 'Brighton Outcomes', ECHR Blog, 23 April 2012, available at: echrblog.blogspot.com [last accessed 19 December 2019]. See also O’Meara, 'Brighton rocked! Next steps for reforming the European Court of Human Rights', UK Constitutional Law Association, 20 April 2012, available at: wp.me/p1cVqo-h6 [last accessed 19 December 2019]; Helfer, supra n 29 at 1; Lambrecht, 'Reforms to Lessen the Influence of the European Court of Human Rights: A Successful Strategy?' (2015) 21 European Public Law 257 at 272.

52 Chrisoffersen and Madsen, 'Postscript: Understanding the Past, Present and Future of the European Court of Human Rights' in Christoffersen and Madsen (eds), The European Court of Human Rights between Law and Politics (2013) at 239. See also Vogiatzis, 'When Reform Meets Judicial Restraint Protocol 15 Amending the European Convention on Human Rights' (2015) 66 Northern Ireland Legal Quarterly 130 at 136.

53 Arnardóttir, 'The Brighton Aftermath and the Changing Role of the European Court of Human Rights' (2018) 9 Journal of International Dispute Settlement 223 at 224.

54 Helfer, supra n 29 at 2; Madsen, supra n 29 at 205; Madsen, 'The Challenging Authority of the European Court of Human Rights: From Cold War Legal Diplomacy to the Brighton Declaration and Backlash' (2016) 79 Law and Contemporary Problems 141 at 144, 175.

55 Christoffersen and Madsen, supra n 52 at 240. See also Madsen, supra n 29 at 200.

56 'Ken Clarke hails deal to overhaul European Court of Human Rights', BBC, 19 April 2012, available at: www. bbc.com [last accessed 19 December 2019]. See also O'Meara, supra n 51: 'the changes are ... marginal'; Elliott, 'After Brighton: Between a Rock and a Hard Place' (2012) Legal Studies Research Paper Series 20/12, at 6, available at: doi.org/10.2139/ssrn.2116344 [last accessed 19 December 2019], stating: 'the essential characteristics of the Convention regime, and of the Court's role within it, are preserved'.

57 See also O'Meara, supra n 51. See Section A of the Brighton Declaration. See also Madsen, supra n 28 at 200.

58 See Section 3 infra. 
in Brussels. ${ }^{59}$ This is also apparent from the title of the Brussels Conference: 'The implementation of the [Convention], our shared responsibility', whereas the other conferences were conferences 'on the Future of the Court'.

The Copenhagen Declaration, like the Brighton Declaration, is less far-reaching than its draft and the parts that were most criticised by civil society and academia were deleted or rewritten. ${ }^{60}$ This declaration does not contain any 'really new or exciting solutions and ideas. ${ }^{61}$ Furthermore, instead of being very critical of the Court or of the Convention, the Copenhagen Declaration is rather positive as it welcomes developments in the Court's case law, ${ }^{62}$ in its working methods ${ }^{63}$ and in the 'efforts of the Court to bring down the backlog' of cases. ${ }^{64}$

The five declarations, in sum, centre on the first problem discussed in Section 2.A (the caseload). The documents address this issue, ${ }^{65}$ albeit without making any proposals that would fundamentally change the object and purpose of the Convention system or the task of the Court in order to address this problem. ${ }^{66}$ The proposed reform, therefore, seems to fall in the first category of reform measures introduced in Section 1. In addition to that, the Brighton Declaration and the Copenhagen Declaration are in part a response to the second 'problem' identified in Section 2.A (discontent with the Court), although this response was not translated into any far-reaching proposals. In fact, the more far-reaching proposals in the drafts did not make it into the adopted text. Those proposals that are contained in the declarations and that aim to reform the functioning of the Court are analysed in the next section.

\section{THE PROPOSALS IN THE DECLARATIONS}

This section divides the proposals into seven themes and into seven corresponding sub-sections. The first sub-section (Section 3.A) examines proposals relating to the Court's general case-processing capacity. The next two sections cover comparable, but more specific themes: the Court's capacity to process clearly inadmissible (Section 3.B) and repetitive (Section 3.C) applications. Section 3.D addresses proposals of a different nature, as they concern the principle of subsidiarity and the margin of appreciation doctrine. Proposals relating to dialogue and the clarity and consistency of the Court's judgments are discussed in Section 3.E and Section 3.F. The last section (Section 3.G) is about just one proposal, the simplified procedure for amending the Convention. This proposal does not fit into any of the preceding thematic sections. In total, 29 proposals or sets of proposals are presented by outlining, where relevant, the proposal itself, the rationale for the proposal, the Court's response to the proposal and whether the proposal has been implemented.

ECtHR, supra n 27 at para 3; Brussels Declaration, Preamble at paras ii-iii.

Ulfstein and Follesdal, 'Copenhagen—much ado about little?', EJIJ: Talk!, Blog, 14 April 2018, available at: www.ejiltalk.org [last accessed 19 December 2019]; Gerards and Lambrecht, supra n 20; Helga Molbæk-Steensig, 'Something Rotten in the State of Denmark?', Verfassungsblog, 26 April 2018, available at: verfassungsblog.de [last accessed 19 December 2019].

Gerards and Lambrecht, supra n 20. See also Ulfstein and Follesdal, supra n 60.

Copenhagen Declaration at paras 29, 31-32.

Ibid. at para 37.

Ibid. at para 47.

Brighton Declaration at para 30.

Ibid. at paras 31, 35(e). 


\section{A. The Court's General Case Processing Capacity}

As explained in Section 2.A, the shared background against which the conferences took place was the Court's caseload crisis. Therefore, it is only logical that the conferences made various proposals to enhance the Court's general case processing capacity, something that has become increasingly relevant now that the Court has managed to filter clearly inadmissible cases efficiently. The three proposals that are discussed here concern the application procedure, the composition of the Chambers and the notion of 'well-established case law' (WECL).

\section{(i) The application procedure}

The Brighton Declaration put forward various ideas to improve the application procedure. Most generally, the States suggested simplifying the communication procedure. ${ }^{67}$ In this regard, the Court amended Rule 47 of the Rules of Court, which amendment brings with it a 'stricter, more formal approach' to the institution of proceedings. ${ }^{68}$ This approach has 'lightened the workload of the Registry and facilitated the speedy processing of applications. ${ }^{69}$ Together with the new rule, the Court introduced a new application form, as the States had proposed. ${ }^{70}$ The form enables the Registry to 'determine straight away the nature and the scope of each new application. ${ }^{71}$ This facilitated the adoption of a 'procedure of immediate simplified communication of Chamber cases' to respondent States by which the application form is forwarded to that States, along with any other documents provided by the applicant, in place of the detailed 'communication report' that used to be sent and had taken the Registry considerable time to draft. ${ }^{72}$ Another suggestion was to facilitate making applications online. ${ }^{73}$ The Court has not implemented this suggestion because a test with sending applications electronically 'revealed that some users may encounter a problem because of the quality of their internet connections. ${ }^{74}$ However, the Court has set up the eComms system, which makes it possible for applicants' representatives to communicate electronically with the Court after the original communication. ${ }^{75}$ Lastly, the States asked the Court to make it possible to submit the claim for and comments on just satisfaction earlier in certain proceedings. ${ }^{76}$ The Court does not seem to have followed up on this proposal. ${ }^{77}$

67 Brighton Declaration at para $20(\mathrm{~g})(\mathrm{i})$.

68 ECtHR, The Interlaken Process and the Court (2013 Report), 28 August 2013, at 12, available at: www.echr. coe.int [last accessed 19 December 2019].

69 ECtHR, The Interlaken Process and the Court (2014 Report), 28 January 2015, at 12, available at: www.echr. coe.int [last accessed 19 December 2019].

70 Brighton Declaration at para 20(g)(ii) and (iv).

71 ECtHR, supra $\mathrm{n} 68$ at 12.

72 ECtHR, The Interlaken Process and the Court (2016 Report), 1 September 2016, at 4, available at: www.echr. coe.int [last accessed 19 December 2019]; ECtHR, Follow-up to the CDDH Report on the Longer-Term Future of the system of the European Convention on Human Rights, DD(2018)60, 19 January 2018, at para 16, available at: rm.coe.int [last accessed 19 December 2019].

73 Brighton Declaration at para 20(g)(i).

74 ECtHR, supra n 68 at 5.

75 ECtHR, 'Information for applicants', available at: www.echr.coe.int [last accessed 19 December 2019].

76 Brighton Declaration at para 20(g)(ii,iv).

77 Rule 60 Rules of Court on claims for just satisfaction has not been amended since 13 December 2004 and the Practice Direction on Just Satisfaction has not been amended since 28 March 2007. 
(ii) The composition of the Chambers

Protocol 14 of the ECHR authorised the Court to request that the Committee of Ministers reduce the number of judges of the Chambers from seven to five. ${ }^{78}$ This would mean that fewer judges would decide a case, thereby increasing the Court's productivity. The Interlaken Declaration encouraged the Court to use this possibility. ${ }^{79}$ Initially, the Court did not prioritise this matter in view of the various other measures that it had to take to implement Protocol $14 .^{80}$ When the Court eventually contemplated the advantage of the measure and its disadvantages, it decided not to make such a request. ${ }^{81}$ The disadvantages include the risk of inconsistent case law, the challenge of maintaining a balanced composition of the Chambers and having to restructure the section system. ${ }^{82}$

(iii) The notion of 'well-established case law'

As a result of Protocol 14, Committees of three judges can adopt a judgment if the case can be decided based on 'well-established case law. ${ }^{83}$ The States stated in Brighton that reliance on WECL should be 'without prejudice to the appropriate examination of the individual circumstances of the case and the non-binding character of judgments against another State Party. ${ }^{84}$ Therefore, the States invited the Court to consult them about its plan to extend its use of the notion of WECL beyond repetitive cases. ${ }^{85}$ However, the Court adopted its broader WECL policy in June 2017, meaning that the Committees will also decide non-repetitive cases the decisions in which are nonetheless based on WECL, so as to increase the Court's capacity. ${ }^{86}$ Only after adopting this new policy did the Court present and discuss the policy with the government agents. ${ }^{87}$ Additionally, in its explanations about the new policy to the Committee of Ministers, the Court did not specifically address the concern of the States. ${ }^{88}$ Nonetheless, it will indicate when it is minded to apply the broader WELC policy, after which a respondent State can argue that a Chamber should decide the case. ${ }^{89}$ Therefore, the Court does not seem to have accepted the States' invitation to consult with them regarding the application of WELC.

\section{B. The Court's Application Filtering Capacity}

In addition to the proposals for enhancing the Court's general case processing capacity, the States deliberated about how a more specific caseload problem-the high number

Article 6 Protocol 14 ECHR; Article 26(1) and (2) ECHR.

Interlaken Declaration, Action Plan at para 10(a).

$\mathrm{CDDH}$, Report containing elements to contribute to the evaluation of the effects of Protocol No. 14 to the Convention and the implementation of the Interlaken and Izmir Declarations on the Court's situation, CDDH(2012)R76 Addendum II, 30 November 2012, at para 16, available at: rm.coe.int/reforming-the-european-conventionon-human-rights-interlaken-izmir-bri/1680695a9d [last accessed 19 December 2019].

Ibid.

Ibid.

Article 28(1)(b) ECHR.

Brighton Declaration at para $\mathrm{D}(20)(\mathrm{f})$. See also Izmir Declaration, Follow-up Plan at para E(3).

Brighton Declaration at para D(20)(f); ECtHR, supra n 39 at para 23.

ECtHR, supra n 52 at para 11 .

Ibid. at para 15 .

Ibid. at paras 10-15.

Ibid. at para 14. 
of clearly inadmissible cases_could be dealt with by enhancing the Court's filtering capacity. Filtering is the task of 'finally disposing of such cases. ${ }^{90}$ Single judges currently fulfil this task. ${ }^{91}$ As noted, the attention of the reform process shifted to other aspects of the caseload problem when it became apparent that this formation could filter efficiently. This sub-section first mentions some more general recommendations for enhancing the Court's filtering capacity and then moves on to discuss the ideas on appointing additional judges, charging fees to the applicants and reducing the time limit for filing an application.

\section{(i) Improving filtering}

The Interlaken Declaration recommended that the Court establish a mechanism within the existing bench to ensure effective filtering, ${ }^{92}$ to evaluate the system of filtering and to explore new possibilities of filtering. ${ }^{93}$ Since single judges can now filter clearly inadmissible cases efficiently, the Court can be taken to have responded adequately to these recommendations. The measures that the Court took to achieve this result include the restructuring of the Registry, the creation of a filtering section and improving its working methods. ${ }^{94}$

\section{(ii) Appointing additional judges}

The Brighton Declaration proposed that 'to enable the Court to decide in a reasonable time the applications pending before its Chambers, it may be necessary . . . to appoint additional judges. ${ }^{95}$ Such judges 'may need to have a different term of office and/or a different range of functions from the existing judges of the Court.' ${ }^{96}$ The Court has not responded to this proposal, but the $\mathrm{CDDH}$ studied it and concluded that there was no basis for thus amending the Convention. ${ }^{97}$ This conclusion was based on the finding that there was no consensus on the issue and that the $\mathrm{CDDH}$ could not envisage the necessary increase in the Court's budget as a result of the measure. ${ }^{98}$ Additionally, the $\mathrm{CDDH}$ referred to the positive development in the field of filtering, ${ }^{99}$ which decreased the added value of the measure.

\section{(iii) Charging fees to the applicants}

The Izmir Declaration invited the Committee of Minsters to examine the possibility of charging fees from the applicants ${ }^{100}$ in order to deter clearly inadmissible

CDDH, Final Report on measures requiring amendment of the European Convention on Human Rights, $\mathrm{CDDH}(2012) \mathrm{R} 74$ Addendum I, 15 February 2012, Appendix IV at para 25, available at: rm.coe. int/168045fdc5 [last accessed 19 December 2019].

91 Article 27(1) ECHR reads: 'A single judge may declare inadmissible or strike out of the Court's list of cases an application submitted under Article 34, where such a decision can be taken without further examination.'

92 Interlaken Declaration, Action Plan at para 6(c)(i).

93 Izmir Declaration, Follow-up Plan at para C(2).

$94 \mathrm{CDDH}$, Report on the question of whether or not to amend the Convention to enable the appointment of additional judges to the Court, $\operatorname{CM}(2013) 176,29$ November 2013, at para 4, available at: search.coe. $\mathrm{int} / \mathrm{cm} /$ Pages/result_details.aspx?ObjectID = 09000016805c6a52 [last accessed 19 December 2019].

95 Brighton Declaration at para 20(e).

96 Ibid. See also Interlaken Declaration, Action Plan at para 6(c)(ii).

$97 \mathrm{CDDH}$, supra n 93 at para 16.

98 Ibid. at paras 5, 15.

99 Ibid.

100 Izmir Declaration, Follow-up Plan at para A(2). 
applications. ${ }^{101}$ The Court was opposed to this 'controversial'102 measure for both practical and principled reasons. ${ }^{103}$ As an alternative measure, the Court's President submitted that legal representation could be made compulsory. ${ }^{104}$ However, upon 'further reflection,', 105 the Court expressed that it was also against the alternative measure. ${ }^{106}$ Neither measure has been adopted.

\section{(iv) Reducing the time limit for filing an application}

Prior to Brighton, the Court informed the States that it was 'envisaging a stricter application of the six-month time-limit' and it suggested reducing the time limit 'considerably.' ${ }^{107}$ The Brighton Declaration endorsed both points. ${ }^{108}$ The Court's suggestion will be implemented by Protocol 15 to the ECHR, which will amend Article 35(1) of the ECHR so that the time limit will be reduced from six to four months. ${ }^{109}$ Although this amendment will mean that the single judges can declare more cases inadmissible and, therefore, that they can filter more cases, the amendment is not presented as a filtering measure. Instead, the amendment is justified with reference to 'the development of swifter communications technology, along with the time limits of similar length in force in the member States.' 110

\section{The Court's Capacity to Process Repetitive Applications}

As noted in Section 2.A, the high number of repetitive applications is another, more specific, caseload problem and one that has remained problematic from Interlaken to Copenhagen. The proposals in this section relate to friendly settlements and unilateral declarations, the pilot judgment procedure, representative applications and single judges.

\section{(i) Facilitating recourse to friendly settlements and unilateral declarations}

The Izmir Declaration underlined 'the importance of the active assistance of the Court to States in their efforts to reach friendly settlements and to make unilateral

$101 \mathrm{CDDH}$, supra n 39 at para 29(ii).

$102 \mathrm{CDDH}$, Final Report on measures that result from the Interlaken Declaration that do not require amendment of the European Convention on Human Rights, CM(2010)161, 2 December 2010, at para 13, available at: search.coe.int [last accessed 19 December 2019].

103 Costa, 'Speech', Izmir Conference, 26 April 2011, at 7, available at: www.echr.coe.int [last accessed 19 December 2019].

104 Ibid. Additionally, prior to the Izmir Conference, the Court President considered 'that compulsory representation by a lawyer could be an effective and appropriate means of ensuring proper legal advice before filing an application and would increase the quality in respect of drafting applications': see CDDH, supra $\mathrm{n}$ 86, Appendix III, Section 2 at para 1.

105 CDDH, supra n 86, Appendix III, Section 2 at para 2.

106 ECtHR, supra n 39 at para 30.

107 Ibid. at para 37. The Court implemented the first point: see ECtHR, 'Stricter conditions for applying to the European Court of Human Rights now in force', ECHR 008 (2014), 9 January 2014, available at: hudoc .echr.coe.int [last accessed 19 December 2019].

108 Brighton Declaration at para 15(a) and (b).

109 Article 4 Protocol 15 ECHR.

110 Explanatory Report to Protocol 15 of the ECHR CETS No 213 at para 21, available at: www.echr.coe.int [last accessed 19 December 2019]. See also ECtHR, supra n 39 at para 37. 
declarations', and encouraged the 'Court's role in this respect.' ${ }^{11}$ Prior to Interlaken, the Court's President already agreed that the States should be encouraged to use these procedures ${ }^{112}$ and he stated in Izmir that the Court facilitates recourse to the procedures. ${ }^{113}$ Furthermore, the Court has developed its practice with regard to these procedures in response to the recommendations in the declarations and with the result that an increasing number of applications are decided based on a unilateral declaration or by a friendly settlement. ${ }^{114}$

(ii) Codifying the pilot judgment procedure and evaluating its effects

The Court developed the pilot judgment procedure in its case law as a mean to deal with repetitive cases, without codifying the new procedure in its Rules of Court during the first years of the procedure's existence. ${ }^{115}$ Therefore, the Interlaken Declaration stressed the 'need for the Court to develop clear and predictable standards' for the pilot judgment procedure 'as regards selection of applications, the procedure to be followed and the treatment of adjourned cases.' ${ }^{16}$ About one year later, the Court adopted Rule 61 of Court on the pilot judgment procedure, a development that the States welcomed in Izmir. ${ }^{117}$ In Interlaken, the Court was also asked to 'evaluate the effects of applying [the pilot judgment procedure] and similar procedures. ${ }^{118}$ The Court has not yet followed up on this request.

\section{(iii) The representative application procedure}

Prior to Interlaken, the Court proposed class actions or collective applications as new ways of dealing with repetitive applications. ${ }^{119}$ In line with the Court's proposal, the Brighton Declaration invited the Committee of Ministers

to consider the advisability and modalities of a procedure by which the Court could register and determine a small number of representative applications from a group of applications that allege the same violation against the same respondent State Party, such determination being applicable to the whole group. ${ }^{120}$

112 Costa, supra n 19 at 6.

113 Costa, supra n 104 at 6.

114 ECtHR, supra n 39 at para 11. See also CDDH, Report containing conclusions and possible proposals for action on ways to resolve the large numbers of applications arising from systemic issues identified by the Court, CM(2013)93 add6, 11 July 2013, at para 21, available at: search.coe.int [last accessed 19 December 2019]; Glas, 'Unilateral Declarations and the European Court of Human Rights: Between Efficiency and the Interests of the Applicant' (2018) 25 Maastricht Journal of European and Comparative Law 607.

115 Glas, 'The Functioning of the Pilot Judgment Procedure of the European Court of Human Rights in Practice' (2016) 43 Netherland Quarterly of Human Rights 41 at 42.

116 Interlaken Declaration, Action Plan at para 7(b).

117 Izmir Declaration, Follow-up Plan at para E(5). See also Costa, supra n 103 at 2.

118 Interlaken Declaration, Action Plan at para 7(b).

119 Costa, supra n 19 at 7. For background information, see ECtHR, The Interlaken Process and the Court (2012 Report), 16 October 2012, at 11, available at: www.echr.coe.int [last accessed 19 December 2019]. Brighton Declaration at para 20(d). 
The CDDH took on this task, finding that the Court already used various procedural tools such as the pilot judgment procedure to handle repetitive applications. It was unclear how a new tool would 'usefully distinguish' itself from the existing tools. ${ }^{121}$ This conclusion seems to have ended the discussion on the representative application procedure.

\section{(iv) Single judges deciding repetitive cases}

As explained above, Committees of three judges decide repetitive and (since June 2017) other cases based on WECL, ${ }^{122}$ whereas single judges filter clearly inadmissible applications. ${ }^{123}$ The Interlaken Declaration asked the Committee of Ministers to consider whether the Convention should be amended so that single judges can also decide repetitive applications. ${ }^{124}$ The $\mathrm{CDDH}$ has not yet considered this issue. ${ }^{125}$ Instead, it has focused on the possibility of appointing additional judges in the context of other proposals. ${ }^{126}$ Neither the Court nor its Presidents have commented on this proposal publicly.

\section{Subsidiarity and the Margin of Appreciation}

As explained in Section 2.A, the Brighton Conference and the Copenhagen Conference took place against the background of growing domestic discontent with the Court. This development explains largely the eight proposals in this section that relate to the subsidiarity principle and the margin of appreciation doctrine. First of all, the States wished to strengthen the appearance of these two notions in both the Court's case law and in the Convention. Additionally, they deemed it desirable to reduce the number of interim measures and to give advanced access to rulings for the parties. The last four proposals relate to admissibility and, more specifically, to separate rulings on admissibility, the exhaustion of domestic remedies rule, the significant disadvantage criterion and the manifestly ill-founded criterion.

\section{(i) The case law}

The States encouraged the Court to 'give greater prominence to' the subsidiarity principle and the margin of appreciation ${ }^{127}$ and to 'avoid reconsidering questions of fact or national law that have been considered and decided by national authorities', as it is not a fourth-instance court. ${ }^{128}$ In response, the Court explained what these concepts entail, without evaluating whether it had changed its approach in view of the declarations. ${ }^{129}$

$121 \mathrm{CDDH}$, Report on the advisability and modalities of a 'representative application procedure', 22 March 2013, $\mathrm{CM}(2013) 32$, at para 31, available at: search.coe.int [last accessed 19 December 2019].

122 See Section 3.A.iii.

123 Articles 27(1) and 28(1)(b) ECHR.

124 Interlaken Declaration, Action Plan at para 7(c)(i).

$125 \mathrm{CDDH}$, supra n 86, Appendix IV at para 12.

126 See Section 3.B.ii.

127 Brighton Declaration at para 12(a). See also Interlaken Declaration, Action Plan at para 9(b); Izmir Declaration, Preamble at para 5; Brighton Declaration at para 11; Brussels Declaration at para 7.

128 Interlaken Declaration, Action Plan at para 9(a). See also Izmir Declaration, Follow-up Plan at paras A(3), $\mathrm{F}(2)$; Copenhagen Declaration at para 28(a).

129 Costa, supra n 19 at 4; Bratza, 'Speech', Brighton Conference, Brighton, 18-20 April 2012, at 5, available at: www.echr.coe.int [last accessed 19 December 2019]; ECtHR, The Principle of Subsidiarity. Note by the Jurisconsult, 8 July 2010, available at: www.echr.coe.int [last accessed 19 December 2019]. 
The Copenhagen Declaration did make this evaluation, claiming that the reform process has resulted in 'strengthening subsidiarity' ${ }^{130}$ This claim leads to two questions: has subsidiarity indeed been strengthened and, if so, is this a result of the declarations? These questions have been the subject of an academic debate that is summarised here.

Quantitative research has established that the Court has increasingly referred to the margin of appreciation and subsidiarity since Brighton. ${ }^{131}$ However, these findings should not be overstated, since qualitative research has revealed that the Court's references to the margin of appreciation are 'rather empty', ${ }^{132}$ turning it 'into a substantively rather empty rhetorical device. ${ }^{133}$ With reference to the first research, Judge Spano concluded cautiously that the Court applies the subsidiarity principle 'more robustly'134 when the national authorities take their Convention obligations seriously. ${ }^{135}$ Other research confirmed that 'the Court is retreating towards more judicial restraint through developments in the margin of appreciation doctrine. ${ }^{136}$ Moreover, research into Article $10 \mathrm{ECHR}$ judgments has found that the Court is willing to 'defer to national authorities ${ }^{137}$ by choosing a systemic rather than 'a substantive analysis in more mature democracies', ${ }^{138}$ although the picture 'remains mixed. ${ }^{139}$ Comparably, research into mainly two judgments (Austin and Others $v$ United Kingdom ${ }^{140}$ and Mouvement Raëlien Suisse $v$ Switzerland ${ }^{141}$ ) has led to the insight that there has been a trend towards 'the operationalisation of the principle of subsidiarity and the margin of appreciation, which leads the Court from an inner, material control of national authorities to an outer, procedural control.' ${ }^{142}$ Another analysis of Mouvement Raëlien Suisse indicated that the Court gave 'unprecedented prominence to the principle of subsidiarity and the margin of appreciation doctrine' in this case. ${ }^{143}$ Furthermore, an analysis of Von Hannover $v$ Germany (No 2) ${ }^{144}$ and again Austin and Others led to the conclusion that the Court seems to have taken 'an approach that looks like one of appeasement

Copenhagen Declaration at para 4. See also Brighton Declaration at para 12(a); Copenhagen Declaration at para 31.

131 Madsen, supra n 29 at 220. See also Mowbray, supra n 18 at 341.

132 Gerards, 'Margin of Appreciation and Incrementalism in the Case Law of the European Court of Human Rights' (2018) 18 Human Rights Law Review 495 at 501.

Ibid. at 497.

134 Spano, supra $\mathrm{n} 7$ at 481 .

135 Ibid. See also Spano, 'Universality or Diversity of Human Rights: Strasbourg in the Age of Subsidiarity?' (2014) 14 Human Rights Law Review 487; Saul, 'The European Court of Human Rights' Margin of Appreciation and the Processes of National Parliaments' (2015) 15 Human Rights Law Review 745 at 772. Arnardóttir, supra n 53 at 227. See also ibid. at 236-7.

137 Cram, supra n 31 at 479.

138 Ibid. at 499.

139 Ibid. at 502.

140 Applications Nos 39692/09 et al., Merits and Just Satisfaction, 15 March 2012.

141 Application No 16354/06, Merits and Just Satisfaction, 13 July 2012.

142 Rui, 'The Interlaken, Izmir and Brighton Declarations: Towards a Paradigm Shift in the Strasbourg Court's Interpretation of the European Convention of Human Rights?' (2013) 28 Nordic Journal of Human Rights 28 at 54.

143 Füglistaler, The Principle of Subsidiarity and the Margin of Appreciation Doctrine in the European Court of Human Rights' Post-2011 Jurisprudence (2016) at 64-5. See also Guillemin, 'Case Law, Strasbourg: Mouvement Raelien Suisse v Switzerland, Of Aliens and Flying Saucers, Strasbourg Observers, Blog, 31 July 2012, available at: strasbourgobservers.com [last accessed 19 December 2019].

Applications Nos 40,660/08 and 60,641/08, Merits and Just Satisfaction, 7 February 2012. 
of certain signatory states. ${ }^{145}$ In short, the literature confirms, albeit cautiously and mainly based on a limited sample of cases, that the Court has placed a greater emphasis on subsidiarity by taking a procedural or systemic approach rather than a substantive approach. This development does not, however, necessarily equal more deference to the domestic authorities. ${ }^{146}$ As Judge Spano explained, the Court only defers if the national authorities have taken their Convention responsibilities seriously, ${ }^{147}$ meaning that the change is more relevant to some States or in some cases rather than to others-as other authors pointed out as well. ${ }^{148}$

Most authors seem to agree that the Court is receptive to the concerns of the States as expressed in the declarations. ${ }^{149}$ According to Arnardóttir, however, the procedural turn in the Court's case law preceded the conferences and was a response of the Court to systemic domestic problems causing many repetitive applications. ${ }^{150}$

\section{(ii) The Convention}

The Brighton Declaration determined that, 'for reasons of transparency and accessibility, a reference to the principle of subsidiarity and the doctrine of the margin of appreciation as developed in the Court's case law should be included in the Preamble to the Convention. ${ }^{151}$ Protocol 15 of the ECHR will implement this amendment. ${ }^{152}$ The Court failed to see 'the need for, or the wisdom of codifying the margin of appreciation, because it is 'a variable notion which is not susceptible of precise definition. ${ }^{153}$ Additionally, the Court doubted that the amendment would help it 'cope more easily with the challenges facing it' ${ }^{154}$ and it was 'uncomfortable with the idea that the Governments can in some way dictate ... how its case law should evolve or how it should carry out [its] judicial functions. ${ }^{155}$ When it became clear that the amendment was unavoidable, the Court urged the States to include the words 'as developed in the Court's case-law', because the margin of appreciation 'varies widely in its relevance and consequence from one context to another. ${ }^{156}$ The States ceded to this request. ${ }^{157}$

145 Fenwick, 'An Appeasement Approach of the European Court of Human Rights?', UK Human Rights Blog, 17 April 2012, available at: ukhumanrightsblog.com [last accessed 19 December 2019].

146 Arnardóttir, 'Organised Retreat? The Move from 'Substantive' to 'Procedural' Review in the ECtHR's Case Law on the Margin of Appreciation', Conference Paper No. 4/2015, at 23, available at: dx.doi.org/ 10.2139/ssrn.2709669 [last accessed 19 December 2019]; Mowbray, supra 17 at 340; Arnardóttir, supra n 53 at 237; Spano, supra $\mathrm{n} 7$ at 492.

147 Spano, supra n 7 at 492-3. See also Çal,, 'Coping with Crisis: Wither the Variable Geometry in the Jurisprudence of the European Court of Human Rights' (2018) 35 Wisconsin International Law Journal 237 at 269.

148 Cram, supra n 31 at 499; Fenwick, supra n 145.

149 Guillemin, supra n 143; Fenwick, ibid.; O’Meara, supra n 29 at 29; Füglistaler, supra n 143 at 64-5; Çalı, supra 147 at 275; Cram, ibid. at 479; Madsen, supra n 29 at 221.

150 Arnardóttir, supra n 146 at 21.

151 Brighton Declaration at para 12(b).

152 Article 1 Protocol 15 to the ECHR.

153 Bratza, supra n 129 at 6.

154 Ibid. at 2.

155 Ibid.

156 Milner, supra 20 at 32, referring to the Comment from the [Court] on the proposed amendment to the Preamble of the ECHR, \#4160804, 23 November 2012.

157 Article 1 Protocol 15 to the ECHR. 
(iii) Reducing the number of interim measures

In Izmir, the States reminded the Court that it should deal with interim measure requests in conformity with the subsidiarity principle ${ }^{158}$ and they expressed their concern over the increase in the number of interim measures requested. ${ }^{159}$ Furthermore, the States asked the Court to consider the merits of cases in which it imposed interim measures with expedition. ${ }^{160}$ The Court agreed that the situation was problematic, because it could not deal with the requests within a reasonable time. ${ }^{161}$ To counter the problem, the Court reorganised its internal set-up for dealing with the requests and it changed its judicial and administrative procedures. ${ }^{162}$ The Court also revised its Practice Direction on Interim Measures ${ }^{163}$ and the Court's President issued a public statement to clarify the responsibilities of the parties involved. ${ }^{164}$ These measures, in combination with a decrease in the number of requests, meant that the situation returned to normal and that the number of requests granted dropped significantly. ${ }^{165}$ The Court also took measures to reduce the time that it takes to consider the merits of cases in which interim measures apply. ${ }^{166}$

(iv) Advance access to the rulings for the parties

The Brighton Declaration invited the Court to make its rulings available to the parties 'a short period of time before their delivery in public. ${ }^{167}$ The reason for this proposal is neither apparent from the declaration nor mentioned in, for example, the CDDH's contribution to the conference. ${ }^{168}$ The Court regarded this plan as 'problematic' because it 'would undermine the important principle of secret deliberations', ${ }^{169}$ without there being 'any strong reason' for doing so. ${ }^{170}$ Furthermore, the Court pointed out that this idea would lead to a 'clear risk of premature disclosure of the result of a case.. ${ }^{\text {, }}$

\section{(v) Separate rulings on admissibility}

The Brighton Declaration proposed that the Court should decide on the question of admissibility separately when a respondent State with 'a particular interest' in a ruling on the effectiveness of a domestic remedy so requests. ${ }^{172}$ This proposal should lead to

158 Izmir Declaration, Follow-up Plan at para A(3).

159 Izmir Declaration, Preamble at para 12. See also Brighton Declaration at para 12(e).

160 Izmir Declaration, Follow-up Plan (2011) at para A(3).

161 ECtHR, supra n 119 at 8.

162 ECtHR, supra n 39 at para 12. See for more information ECtHR, supra n 119 at 8-9.

163 CDDH, Report on interim measures under Rule 39 of the Rules of Court, 22 March 2013, CDDH(2013)R77, at para 12, Addendum II, available at: rm.coe.int [last accessed 19 December 2019].

164 ECtHR, supra n 119 at 8.

165 ECtHR, supra n 39 at para 12; CDDH, Contribution to the Ministerial Conference organised by the United Kingdom Chairmanship of the Committee of Ministers, CDDH(2012)R74 Addendum III, 15 February 2012, at para 19, available at: www.coe.int [last accessed 19 December 2019]; CDDH, supra n 163 at para 12. CDDH, ibid. at para 14. See also ECtHR, supra n 68 at 11.

167 Brighton Declaration at para 20(g)(iii).

$168 \mathrm{CDDH}$, supra n 165 at paras 16-21 relating to 'The role of the Court and its relations with national authorities'.

169 ECtHR, supra n 119 at $14-15$.

170 Ibid.

171 Ibid.

172 Brighton Declaration at para 15(f). 
an amendment of the Rules of Court. ${ }^{173}$ According to the CDDH, a State should be able to file such a request, 'especially in order to avoid the risk of repetitive cases. ${ }^{174}$ The Court qualified the proposal as 'unjustified' because it goes 'against the spirit' of Article 29(1) of the ECHR, which makes deciding on admissibility and merits in one judgment 'the norm.' ${ }^{\text {'75 }}$ The proposal was also 'unnecessary', according to the Court, because it can already decide on admissibility separately on the invitation of a State. ${ }^{176}$

\section{(vi) Developing the exhaustion of domestic remedies rule}

The Brighton Declaration invited the Court 'to develop its case law on the exhaustion of domestic remedies so as to require an applicant ... to have argued before the national courts ... the alleged violation of the Convention rights or an equivalent provision of domestic law. ${ }^{177}$ This proposal is meant to enable the domestic judges to apply the Convention in the light of the Court's case law. ${ }^{178}$ The Court reacted by noting 'simply that the wording used in ... the Declaration ... seems very close to the existing caselaw, which requires the applicants to have raised their complaint at least in substance. ${ }^{179}$ In other words, the Court did not consider it to be necessary to change its approach in response to the invitation. Nevertheless, the Copenhagen Declaration welcomed 'the Court's continued strict and consistent' application of the admissibility criteria, 'including by requiring applicants to be more diligent in raising their Convention complaints domestically. ${ }^{180}$ This statement could be read as complimenting the Court for accepting the invitation in the Brighton Declaration, but is without a factual basis. ${ }^{181}$

\section{(vii) Applying and amending the significant disadvantage rule}

Protocol 14 to the ECHR amended the Convention so the Court can declare an application inadmissible if the applicant has not suffered a significant disadvantage. ${ }^{182}$ This amendment is supposed to help the Court to focus on cases warranting an examination on their merits. ${ }^{183}$ In Interlaken and Izmir, the Court was asked to 'give full effect to the new admissibility criterion. ${ }^{184}$ However, by the time the Brighton Conference took place, the Court had to admit that the criterion 'has yet to achieve the impact foreseen by the drafters' of Protocol 14. ${ }^{185}$ This was probably because, during its first two years, only the Chambers and the Grand Chamber could use the criterion ${ }^{186}$ and because it was easier and faster to declare a case inadmissible on another ground. ${ }^{187}$ After the first

173 Ibid.

$174 \mathrm{CDDH}$, supra n 165 at para 17 (iv).

175 ECtHR, supra n 119 at 14.

176 Ibid. See Rule 54A(1) Rules of Court.

177 Brighton Declaration at para 15(g). See also CDDH, supra n 165 at para 17; Article 35(1) ECHR.

178 Brighton Declaration at para $15(\mathrm{~g})$. See also CDDH, ibid. at para 17.

179 ECtHR, supra n 119 at 14.

180 Copenhagen Declaration at para 32 (emphasis added).

181 As far as the author is aware, there is no academic literature confirming this statement.

182 Article 35(3)(b) ECHR.

183 Explanatory Report to Protocol 14 of the ECHR at para 35.

184 Interlaken Declaration, Action Plan at para 9(c); Izmir Declaration, Follow-up Plan at para F(2).

185 ECtHR, supra n 39 at para 10.

186 Article 20(2) Protocol 14 to the ECHR.

$187 \mathrm{CDDH}$, supra n 80 at para 31. 
two years, the Court used the criterion more and, thus, followed up on the call of the States. ${ }^{188}$

In Brighton, the States decided to remove one of the two safeguard clauses accompanying the new admissibility criterion ('and provided that no case may be rejected on this ground which has not been duly considered by a domestic tribunal'). ${ }^{189}$ The amendment should 'give greater effect to the maxim de minimis non curat praetor' ${ }^{190}$ so the Court can focus on its subsidiary role. ${ }^{191}$ The Court did not express 'any particular views on this provision other than general support. ${ }^{192}$ The amendment is foreseen in Protocol 15 to the ECHR. ${ }^{193}$

\section{(viii) Applying the manifestly ill-founded criterion}

According to the Brighton Declaration, an application should be declared inadmissible as manifestly ill-founded ${ }^{194}$ when it raises 'a complaint that has been duly considered by a domestic court applying the rights guaranteed by the Convention in light of wellestablished case law. ${ }^{195}$ The Court was encouraged to 'have regard to the need to take a strict and consistent approach in declaring such applications inadmissible. ${ }^{196}$ In reaction, the Court's President confirmed that it is 'the Court's practice to reject a case as inadmissible where it finds that the complaint has been fully and properly examined in Convention terms by the domestic courts. ${ }^{197}$ In other words, it did not seem to be necessary to implement this recommendation because the Court already did what was recommended.

\section{E. Dialogue}

Besides the general references to the importance of dialogue in the declarations, ${ }^{198}$ the States made four specific suggestions to enhance the Court's dialogue between themselves and the Court's judges. These suggestions concern advisory opinions, government agents, third-party interventions and the referral procedure. Additionally, the States welcomed the Court's creation of the Superior Courts Network, ${ }^{199}$ which the Court established with a view to ensuring the exchange of information between itself and national courts belonging to the network. ${ }^{200}$ The courts exchange information on the Court's case law, on Convention law and on the domestic law of the national

OSJI, The Application of the 'Significant Disadvantage' Criterion by the European Court of Human Rights (November 2015) at 3, available at: www.opensocietyfoundations.org [last accessed 19 December 2019].

190 Explanatory Report to Protocol 15 to the ECHR at para 23.

191 CDDH, supra n 86 at para 3(e).

192 Milner, supra n 20 at 39.

193 Article 5 Protocol 15 to the ECHR.

194 Article 35(3)(b) ECHR.

195 Brighton Declaration at para 15(d).

196 Ibid.

197 Bratza, supra n 129.

198 See, for example, Brighton Declaration at para 12(c); Brussels Declaration, Action Plan at para B(1)(a)-(b); Copenhagen Declaration at paras 33, 35-36.

199 Brussels Declaration, Action Plan at para B(1)(b); Copenhagen Declaration at para 37(b).

200 ECtHR, Cooperation Charter of the Superior Courts Network (SCN) at para 1, available at: www.echr.coe.int [last accessed 19 December 2019]. See also ECtHR, Operational Rules of the Superior Courts Network, 13 April 2018, available at: www.echr.coe.int [last accessed 19 December 2019]. 
courts. $^{201}$ The topic of dialogue is closely related to that of subsidiarity, in the sense that enhanced interaction between the Court and domestic authorities can be regarded as a means to foster the implementation of the Convention, in keeping with the subsidiarity principle. $^{202}$ Nevertheless, the proposals relating to dialogue are discussed in a separate sub-section, due to the prominence given to this concept in recent discussions on reform.

\section{(i) Advisory opinions}

The Izmir Declaration observed 'that some states parties have expressed interest in a procedure allowing the highest national courts to request advisory opinions from the Court concerning the interpretation and application of the Convention. ${ }^{203}$ Therefore, the States invited the Committee of Ministers to reflect on the advisability of introducing such a procedure. ${ }^{204}$ The CDDH studied the pros and cons of the procedure, without concluding whether or not the procedure should be adopted. ${ }^{205}$ The pros apparently convinced the States, as the Brighton Declaration instructed the Committee of Ministers to draft an optional protocol to the Convention that would establish the procedure. ${ }^{206}$ The Court was not opposed to the procedure in principle. ${ }^{207}$ According to the Court, advisory opinions aim 'at reinforcing domestic implementation of the Convention in accordance with the principle of subsidiarity' and 'the longer term objective would clearly be to ensure that more cases were dealt with satisfactorily at national level. ${ }^{208}$ The procedure is now laid down in Optional Protocol 16 to the ECHR, which is currently in force for 14 States Parties. The content of this protocol is generally in conformity with the Court's preferences, except that the Court preferred to have discretion to give reasons for refusal to accept a request for an advisory opinion, ${ }^{209}$ whereas the Protocol imposes a duty on the Court to do so. ${ }^{210}$

\section{(ii) Meetings with government agents}

In the Izmir Declaration, the Court was encouraged to organise meetings with the government agents 'on a regular basis so as to further good cooperation.' ${ }^{211}$ According

201 Cooperation Charter of the SCN, supra n 200 at para 1.

202 See, for example, Preamble Protocol 16 to the ECHR.

203 Izmir Declaration, Preamble at para 13.

204 Ibid., Follow-up Plan at para D(1).

$205 \mathrm{CDDH}$, supra n 86, Appendix V at paras 3-4.

206 Brighton Declaration at para 12(d). See for the drafting history Explanatory Report to Protocol 16 of the ECHR at paras 1-6.

207 Bratza, supra n 129 at 6. See also Costa, supra n 13 at 5; ECtHR, supra n 39 at para 28.

208 ECtHR, Reflection Paper on the Proposal to Extend the Court's Advisory Jurisdiction, at para 2, available at: www.echr.coe.int [last accessed 19 December 2019]. See also CDDH, supra n 86, Appendix V at para 3.

209 ECtHR, supra n 208 at para 35.

210 Article 2(1) Protocol 16 to the ECHR. To date the Grand Chamber of the Court has delivered one advisory opinion: see Advisory opinion concerning the recognition in domestic law of a legal parent-child relationship between a child born through a gestational surrogacy arrangement abroad and the intended mother, Request No P16-2018-001, 10 April 2019; and on 2 October 2019 a request for an advisory opinion was accepted: see European Court of Human Rights, 'A request by the Constitutional Court of Armenia for an advisory opinion under Protocol No 16 has been accepted, Press Release', ECHR 343 (2019), 11 October 2019.

211 Izmir Declaration, Follow-up Plan at F(2)(f). See also Brighton Declaration at para 12(c)(i); CDDH, Draft CDDH Report containing conclusions and possible proposals for action concerning the procedure for the 
to the Court, such meetings had been intensified even before the Izmir Conference took place. $^{212}$ The States applauded the Court's efforts in this regard in the Copenhagen Declaration, by welcoming the 'ongoing constructive dialogue' between the Court and government agents. ${ }^{213}$ However, the Brighton Declaration specifically advocated for dialogue between these two actors through consultations on proposals to amend the Rules of Court. ${ }^{214}$ The Court's President expressed his 'surprise' at the demands of States wishing to play a role in the adoption of the Rules of Court. ${ }^{215} \mathrm{He}$ added critically: ${ }^{216}$

While we work tirelessly every day to address [various] problems ..., some, instead of solving these crucial problems, raise others, such as this one, which is of no urgency. I see this as a desire to exercise control over our Court which, I feel, is inconsistent with the current challenges. So let us focus on what is essential.

Moreover, the Court explained in a report in 2015 that it already collects the views of government agents and other stakeholders on amendments to the Rules of Court that go beyond internal matters. ${ }^{217}$ In spite of these initial reactions to the proposal in the Brighton Declaration, the Court has now adopted a Rule of Court obliging the Registrar to inform the States of any proposals to amend the Rules of Court 'which directly concern the proceedings before it and invite them to submit written comments. ${ }^{218}$

\section{(iii) Supporting third-party interventions}

The Copenhagen Declaration qualified third-party interventions as 'an important way to engage in dialogue with the Court. ${ }^{219}$ The Court agreed that, 'in relation to the development of its case law', third-party interventions are an 'appropriate' mechanism for dialogue. ${ }^{220}$ According to the Court, this mechanism 'does not appear to be used to its fullest potential. ${ }^{221}$ The States apparently concur, since they asked the Court to support third-party interventions by two means.

amendment of the Rules of Court and the possible 'upgrading' to the Convention of certain provisions of the Rules of Court, GT-GDR-G(2014)R2 Addendum I, 16 October 2014, at paras 4-9, available at: rm.coe.int [last 19 December 2019]. Spielmann, 'Le succès et les défis posés à la Cour, perçus de l'intérieur' (L'avenir à long terme de la Cour européenne des droits de l'homme, Oslo 7 April 2014), available at: www.echr.coe.int [last accessed 19 December 2019]. See for the translation CDDH, supra $n 211$ at $\mathrm{n} 3$.

217 ECtHR, The Interlaken Process and the Court (2015 Report), 12 October 2015, at 8, available at: www.echr.coe.int [last accessed 19 December 2019]. See also CDDH, supra n 165 at para 21.

218 Rule 116(2) Rules of Court.

219 Copenhagen Declaration at para 34.

220 ECtHR, Opinion on the Draft Copenhagen Declaration, 19 February 2018, at para 16, available at: www.echr.coe.int [last accessed 24 April 2019].

221 Ibid. See also Glas, 'State Third-Party Interventions before the European Court of Human Rights: The 'What' and 'How' of Intervening' (2016) 5 European Journal of Human Rights 539 at 543. 
The first means is to give 'notice in a timely manner of upcoming cases that could raise questions of principle. 222 The CDDH had made a comparable proposal in 2010 already. ${ }^{223}$ The Court does not seem to have acted upon that proposal, which makes one wonder whether it will act upon the proposal in the Copenhagen Declaration. Perhaps the Court does not consider it necessary to do anything with this idea, because it already publishes press releases when a Chamber intends to relinquish jurisdiction to the Grand Chamber and when the Grand Chamber panel accepts a case for referral. ${ }^{224}$ The second means is to ensure 'that questions to the parties are made available at an early stage and formulated in a manner that sets out the issues of the case in a clear and focused way. 225 The Court has not responded to this proposal, perhaps because it already publishes the statements of facts and questions to the parties on HUDOC shortly after communication. ${ }^{226}$ The second part of this proposal may imply that the statements are currently insufficiently clear and focused, whereas it is uncertain if this is true. In this respect, it is relevant to observe that, as part of the immediate simplified communication procedure, ${ }^{227}$ the parties already 'receive more detailed questions ... to draw out more clearly the issues of Convention law. 228

\section{(iv) Indicating support for referral}

The Copenhagen Declaration also invited the Court 'to adapt its procedures to make it possible for other states parties to indicate their support for the referral of a Chamber case to the Grand Chamber. ${ }^{229}$ Making this possible, according to the States, 'may be useful to draw the attention of the Court to the existence of a serious issue of general importance within the meaning of Article 43(2) of the ECHR. ${ }^{230}$ The Court stated prior to Copenhagen that, if such a proposal would be accepted, it 'would be open to examining' it 'in greater detail.'. 231 So far, the Court has not yet amended its Rules of Court accordingly. ${ }^{232}$

\section{F. Clarity and Consistency of the Judgments}

The States have warned that the high number of applications, amongst other developments, ${ }^{233}$ threatens the 'quality and in particular the clarity and consistency' of the judgments. ${ }^{234}$ In the light of this warning, the declarations stress the importance

Copenhagen Declaration at para 39(a)-(b).

CDDH, supra n 102 at para 8 .

These press releases can be found in the HUDOC 'press collection'. Grand Chamber cases are usually cases raising questions of principle: see Articles 30 and 43(2) ECHR.

Copenhagen Declaration at para 39(a)-(b).

To illustrate: on 6 November 2018, a case that was communicated 19 October 2018 was already available on HUDOC.

See Section 3.A.i.

ECtHR, supra n 72 at para 20.

Copenhagen Declaration at para 38.

Ibid.

ECtHR, supra n 220 at para 17.

See Rule 73 Rules of Court in particular.

Interlaken Declaration, Preamble at paras 7-8. See also Brighton Declaration at para 5; Brussels Declaration, Action Plan at para B(1).

Copenhagen Declaration at para 27. 
of 'a uniform and rigorous application' of the admissibility criteria, ${ }^{235}$ 'a consistent application of the principles of interpretation ${ }^{236}$ and consistency in the application of 'issues of general principle. ${ }^{237}$ The Copenhagen Declaration subsequently welcomed the 'efforts taken by the Court to enhance the clarity and consistency of its judgments. 238

Two proposals that the States put forward specifically relate to the consistency of the Court's judgments. These proposals pertain to the relinquishment of jurisdiction to the Grand Chamber and the composition of this formation, which is the 'Convention mechanism for avoiding inconsistency.239 Two other suggestions concern aspects of the clarity of the case law: the reasoning of refusals to refer and of interim measures decisions. Prior to Brussels, the Court itself had already announced that it would adopt another measure that enhances the giving of reasons: providing brief reasons for inadmissibility decisions of single judges. ${ }^{240}$ The States welcomed this news in Brussels. $^{241}$ The last proposal in this section is the publication of the rules on just satisfaction. Besides this, the Interlaken Declaration also called on the Court to ensure 'that comprehensive and objective information is provided to potential applicants on the Convention and [its] case-law. ${ }^{242}$ Subsequent declarations welcomed the Court's response to this call. ${ }^{243}$

\section{(i) No right to object to relinquishment}

A Chamber 'may' relinquish jurisdiction in favour of the Grand Chamber, inter alia, in the circumstance that the resolution of a question might have a result inconsistent with a previous judgment. ${ }^{244}$ Relinquishment is currently permitted if the parties to a case do not object. ${ }^{245}$ To reinforce the role of the Grand Chamber 'as the principal guarantor of case-law consistency, ${ }^{, 24}$ the Court amended its Rules of Court to oblige a Chamber to relinquish jurisdiction in the said circumstance. ${ }^{247}$ The Court advised the States that this amendment would only be effective if they would renounce their right to object to relinquishment. ${ }^{248}$ The States followed the Court's advice and expressed

Interlaken Declaration, The Conference at para 4. See also Izmir Declaration, Follow-up Plan at para $\mathrm{F}(2)(\mathrm{a})$; Brighton Declaration at para 14.

236 Izmir Declaration, The Conference at para 5.

237 Brighton Declaration at para 23.

238 Copenhagen Declaration at para 29.

239 ECtHR, supra n 39 at para 15.

240 Brussels Declaration, Action Plan at para A(1)(c).

241 Ibid.

242 Interlaken Declaration, Action Plan at para 6(a).

243 Izmir Declaration, Follow-up Plan at para F(4); Brighton Declaration at para 15(e); Brussels Declaration at para 4. See also ECtHR, supra n 39 at paras 7-8; ECtHR, supra n 119 at 5-7; ECtHR, supra n 68 at 6; ECtHR supra n 69 at 5; ECtHR, supra n 217 at 5.

ECtHR, supra $n 39$ at para 16; Rule 72(2) Rules of Court (amended on 6 February 2013). See also CDDH, supra n 165; CDDH, Draft Collective Response to the Court's Jurisconsult's notes on the principle of subsidiarity and on the clarity and consistency of the Court's case law, DH-GDR(2001)R7 Addendum 1, 21 June 2011 (not available online). 
in the Brighton Declaration that this right should be removed from the Convention. ${ }^{249}$ The amendment is included in Protocol 15 to the ECHR. ${ }^{250}$

\section{(ii) Changing the composition of the Grand Chamber}

At present, the Grand Chamber is composed of the Court's President and Vice Presidents, the section Presidents, the national judge and other judges, who are selected by drawing of lots. ${ }^{251}$ The Brighton Declaration invited the Court to consider whether the composition of this formation 'would be enhanced by the ex officio inclusion of the Vice Presidents of each Section.'252 The Court refuted this idea because it would mean that eleven ex officio judges and only six other judges would be involved in a Grand Chamber case. ${ }^{253}$ Consequently, it would be difficult to achieve 'balance in the composition of every Grand Chamber, especially a geographical balance. ${ }^{254}$ The Court added to this objection that 'regular involvement in Grand Chamber cases is an important and valued aspect of the work of all of the judges of the Court. ${ }^{255}$

\section{(iii) Reasoning for refusals to refer}

In order to avoid repetitive requests for referral and to ensure a better understanding of the Chamber judgments, the States asked the Court to provide reasons for its refusals of requests for referral. ${ }^{256}$ The Court responded that this plan 'lacks any basis in the text of the Convention, ${ }^{257}$ since the Convention does not require the Court to reason these refusals. ${ }^{258}$ Additionally, the Court made clear that the plan would impose a 'real and unnecessary burden' on it. ${ }^{259}$ The Court also argued against the plan by pointing out that the procedure before the Panel that decides on the requests does not lend itself to the giving of reasons, since this body 'acts as an intermediary filtering body exercising a wide discretion based on broadly defined criteria. ${ }^{260}$ Moreover, the plan 'could affect the integrity and finality of Chamber judgments' and may require the introduction of an adversarial procedure in the interests of fairness and the good administration of justice. ${ }^{261}$ Instead of following the States' request, the Court published a memorandum on the general practice with regard to requests for referral ${ }^{262}$ and it has adopted the practice of informing the parties of the composition of the

249 Brighton Declaration at para 25.

250 Article 3 Protocol 15 to the ECHR. See for information about the drafting process: see Milner, supra n 20 at 36 .

251 Rule 24(1) Rules of Court.

252 Brighton Declaration at para 25(e).

253 ECtHR, supra n 119 at 12.

254 Ibid.

255 Ibid.

256 Izmir Declaration, Follow-up Plan at para F(2)(e); Brussels Declaration, Action Plan at para 1(d).

257 ECtHR, The General Practice Followed by the Panel of the Grand Chamber when Deciding on Requests for Referral in Accordance with Article 43 of the Convention, October 2011, at para 17, available at: www.echr. coe.int [last accessed 19 December 2019]; ECtHR, supra $n 67$ at Appendix II.

258 Article 45 ECHR; Explanatory Report to Protocol 11 of the ECHR at para 105.

259 ECtHR, supra n 119 at 11-12.

260 ECtHR, supra n 257 at para 18. See more elaborately ECtHR, supra n 72 at Appendix II.

261 ECtHR, supra n 257 at para 19.

262 Ibid. 
Panel that decides on a request. ${ }^{263}$ The Court adopted these two alternative measures because it acknowledged that parties to a case have an interest in knowing more about referral. $^{264}$

(iv) Reasoning interim measures decisions

To enhance the clarity of its case law, the States have also stimulated the Court to provide brief reasons for its decisions imposing interim measures. ${ }^{265}$ Before this suggestion was made, the Registry had already explained that the giving of reasons would increase the Court's workload and even duplicate the Court's work when a case is communicated immediately. $^{266}$ These consequences are problematic because they slow down the imposition of interim measures, which by definition need to be applied urgently. ${ }^{267}$ In place of implementing the proposal, the Court published statistical information on the reasons for rejecting requests in 2015. According to the Court, this publication helped explain its practice regarding interim measures. 268

(v) Publishing the rules on just satisfaction

The Izmir Declaration invited the Court to publish its internal guidelines on the application of Article 41 of the ECHR, including the level of just satisfaction which might be expected in different circumstances. ${ }^{269}$ The rationale behind this proposal seems to be that the applicants increasingly regard the Court as a 'court of compensation', supposedly because they do not understand how the Court calculates its awards of just satisfaction. ${ }^{270}$ The Court explained that the mentioned guidelines aid it 'in taking what are essentially decisions in equity' and that, therefore, it is not necessary to publish them. ${ }^{271}$ Moreover, the Court made clear that it is already possible to discern a pattern in its awards in repetitive cases. ${ }^{272}$

\section{G. The Simplified Procedure for Amending the Convention}

The last proposal that is discussed here is a simplified procedure for amending the Convention provisions of an organisational nature. Such provisions concern, for example, the judicial formations of the Court. This proposal is dealt with in a separate section, because its aim - 'making the Convention system more flexible and capable of adapting

264 Ibid.

265 Brussels Declaration, Action Plan at para A(1)(d).

266 CDDH, supra n 163 at para 33.

267 ECtHR, supra n 72 at 20.

268 Ibid. at Appendix III.

269 Izmir Declaration, Follow-up Plan at para F(2).

$270 \mathrm{CDDH}$, The Longer-term Future of the System of the European Convention on of Human Rights, 11 December 2015 , at para 148 , available at: rm.coe.int/the-longer-term-future-of-the-system-of-the-europeanconvention-on-hum/1680695ad4 [last accessed 19 December 2019].

271 ECtHR, Comment from the Court on the report of the CDDH on the longer-term future of the Convention system, at para 9, available at: www.echr.coe.int [last accessed 19 December 2019]. Ibid. 
to new circumstances'-is different from the aims of the measures in the previous sections. $^{273}$

The Interlaken Declaration already stressed the need for introducing such a procedure and instructed the Committee of Ministers to examine the matter. ${ }^{274}$ The States were also in favour of the procedure when they adopted the declarations in Izmir and Brighton. ${ }^{275}$ Furthermore, the Court evaluated the idea positively, ${ }^{276}$ qualifying the fact that provisions of an organisational nature appear in the Convention as a 'bureaucratic constraint' and an 'anomaly. ${ }^{277}$ About a month after the Brighton Conference, the $\mathrm{CDDH}$ published its report on such a procedure, finding that it would be beneficial to the Convention system and that it should be introduced. ${ }^{278}$

Despite these positive noises, neither the Brussels Declaration nor the Copenhagen Declaration refers to the procedure and the procedure has not been introduced. ${ }^{279}$ This unexpected twist is due to the CDDH's conclusion that it would not at present be opportune' to draft a protocol for the procedure. ${ }^{280}$ The $\mathrm{CDDH}$ arrived at this conclusion because the protocol would 'involve a considerable degree of complexity' and because other issues should be given priority. ${ }^{281}$ Additionally, the CDDH pointed out that some parliaments may not ratify the protocol and that some States may have constitutional difficulties in applying the procedure. ${ }^{282}$

\section{CONCLUSION}

This article set out to examine what has become of the proposals that the States made in the five declarations to reform the functioning of the Court. The previous section addressed this matter in respect of the individual proposals. This section takes a more general approach and draws conclusions based on the proposals that have not been implemented (Section 4.A) and then repeats this exercise for the proposals that have been implemented (Section 4.B). Some final observations characterising the changes that the proposals have brought end this section as well as this article (Section 4.C).

273 Ministers' Deputies, Interim report of the Group of Wise Persons to the Committee of Ministers, CM(2006)88, 10 May 2006, at para 36, available at: rm.coe.int/16805d7ff7 [last accessed 19 December 2019].

274 Interlaken Declaration, The Conference at para 10 and Action Plan at para 12.

275 Izmir Declaration, Follow-up Plan at para G; Brighton Declaration at para 37.

276 Costa, supra n 14 at 4; Costa, supra n 103 at 5-6.

277 Costa, supra n 14 at 4.

$278 \mathrm{CDDH}$, Final report on a simplified Convention amendment procedure, 22 June 2012, at para 32(a-b), available at: rm.coe.int [last accessed 19 December 2019].

279 The reference to the 'need to simplify the procedure for amending Convention provisions of an organizational nature' was apparently removed from the Brussels Declaration, as proposed by non-governmental organisations in response to the draft: see Joint NGO Statement on the draft Brussels Declaration on the 'Implementation of the European Convention on Human Rights, our shared responsibility', at 2, available at: www.hrw.org [last accessed 19 December 2019].

$280 \mathrm{CDDH}$, supra n 278 at para 33.

281 Ibid. at para 33.

282 Ibid. 


\section{A. Unimplemented Proposals}

First of all, it is striking that the proposals that have not been implemented outnumber the proposals that have been implemented. ${ }^{283}$ This finding suggests that the influence of the declarations on the functioning of the Court should not be overstated. Their influence, however, also depends on the measures have been implemented and their impact, as will be elaborated in Section 4.B.

The reasons for lack of implementation of a measure are diverse, but one stands out: the Court has discretion to implement the measure and opposes it, sometimes in language that reveals its irritation with the States. ${ }^{284}$ Whether the proposals that this article examined have had any effect depends, therefore, largely on whether the Court responded favourably to them. The States may not welcome this finding because it means that they cannot use the declarations to exert much pressure on the Court to change its course. This finding goes to show that, even though 47 States unanimously adopted the declarations at high-level conferences, the Court nevertheless feels free to be critical and to decline the invitations in the declarations. In this regard, it is also telling that the only proposal relating to the clarity and consistency of the judgments that the Court has implemented is the one that the Court proposed itself. ${ }^{285}$ The Court has also exerted influence on the declarations in another way because it proposed two amendments to the Convention that the States accepted and presented in the Brighton Declaration. ${ }^{286}$ However, the Court's opposition to a measure does not always mean that the measure will not be implemented as evidenced by the future amendment to the Convention's preamble. ${ }^{287}$

The source of the Court's opposition differs and it may rely on multiple reasons for opposing just one proposal. The Court has raised practical objections to a proposal, ${ }^{288}$ for example relating to its workload ${ }^{289}$ or the risk of inconsistent case law. ${ }^{290}$ Furthermore, the Court has relied on principled reasons ${ }^{291}$ which, for example, have to do with the Convention and/or the nature of a procedure ${ }^{292}$ or the composition of the Grand Chamber, which the Court would like to keep balanced. ${ }^{293}$ The Court, therefore, carefully guards itself against proposals which would have practical repercussions and proposals which would not suit the current Convention system. Regarding some proposals, the Court is not greatly opposed to them, but points out that it is

The proposals in these Sections have not been implemented: 3.A.i (partially not), 3.A.ii, 3.A.iii, 3.B.ii, 3.B.iii, 3.C.ii (partially not), 3.C.iii, 3.C.iv, 3.D.iv, 3.D.v, 3.D.vi, 3.D.viii, 3.E.iii, 3.E.iv, 3.F.ii, 3.F.iii, 3.F.iv. 3.F.v, 3.G. The proposals in these Sections have been implemented: 3.A.i (partially), 3.B.i, 3.B.iv, 3.C.i, 3.C.ii (partially), 3.D.i, 3.D.ii, 3.D.iii, 3.D.vii, 3.E.i, 3.E.ii, 3.F.i. Admittedly, some proposals will only apply once Protocol 15 to the ECHR enters into force, which may happen soon since only two States remain to ratify the Protocol on 19 December 2019, see for up to date information: www.coe.int/en/web/conventions/fu 11-list/-/conventions/treaty/213 [last accessed 19 December 2019]. 
essentially already doing what the States ask of it, which makes implementing the proposals unnecessary. ${ }^{294}$ This reaction goes to show that the proposals are not always very innovative.

Thus, opposition by the Court is the main reason why many proposals have never been carried out. There are, however, also other reasons for this. One reason is that the CDDH advises against some proposals: ${ }^{295}$ for example, the CDDH has concluded that a proposal would not add much value ${ }^{296}$ or that proposal is overly complex. ${ }^{297}$ Sometimes, it is not so clear why a proposal has not been picked up on. ${ }^{298}$ The States could look into such proposals again. This also applies to the simplified amendment procedure, considering that many actors responded favourably to this idea. ${ }^{299}$

\section{B. Implemented Proposals}

The proposals that have been implemented can provide us with some insight into the changes that the Convention system has gone through since Interlaken and therefore roughly since the entry into force of Protocol 14 on 1 June $2010 .{ }^{300}$ This is possible because many changes that have taken place since originated in the declarations. ${ }^{301}$ Additionally, some changes, although they did not originate in a declaration, were welcomed in a declaration as discussed above (the Superior Courts Network and the giving of reasons in single judge decisions) and are taken into consideration here. ${ }^{302}$ This section discusses the implemented proposals keeping in mind the background against which the conferences took place. ${ }^{303}$ The Court has taken a considerable number of practical measures that have significantly enhanced its ability to handle its caseload, which was one of the two background factors discussed previously. ${ }^{304}$ The Court achieved this by developing its general case processing capacity, its filtering capacity and its capacity to process repetitive applications. These practical measures include a new application form, amendment to Rule 47, immediate simplified communication procedure, ${ }^{305}$ restructuring of the Registry, creation of a filtering section, improvement in the working methods ${ }^{306}$ and facilitating recourse to friendly settlements and unilateral declarations. ${ }^{307}$ Probably, the Court's improved information policy also contributed to lowering its caseload. ${ }^{308}$ Many such measures were particularly efficient, because Protocol 14 had already laid down the groundwork for enhancing the Court's case

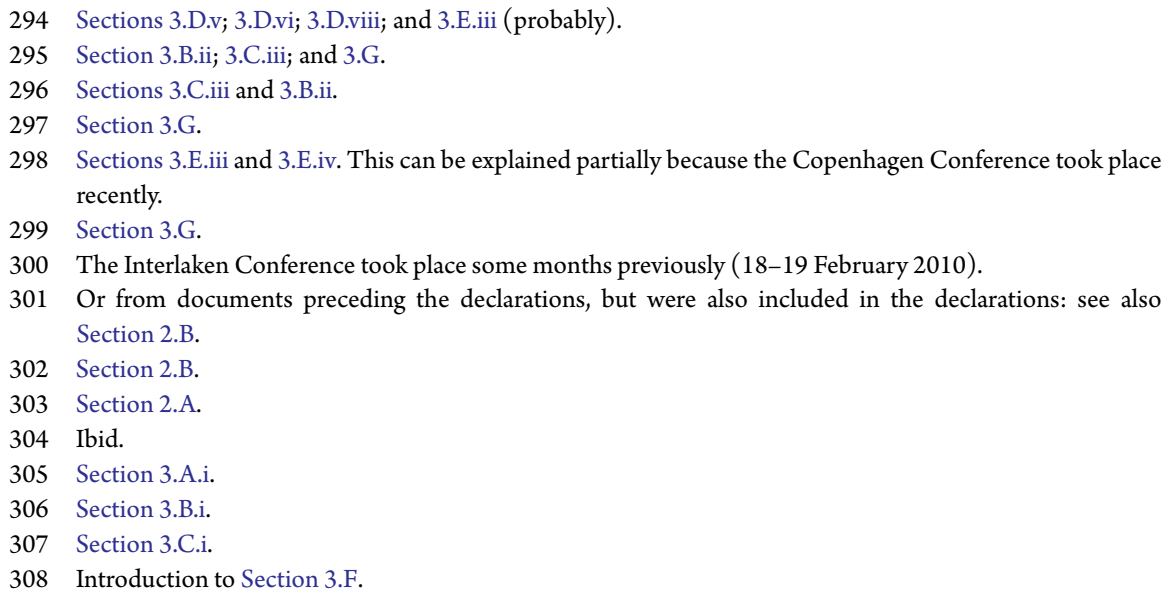


processing capacity. Furthermore, once Protocol 15 of the ECHR enters into force (two further ratifications are required), the Court's filtering capacity will increase further as a result of the reduction of the time limit for filing an application and of the deletion of a safeguard clause from the significant disadvantage admissibility criterion. ${ }^{309}$ Although discussed as a measure that relates to subsidiarity, it is also relevant to mention here that the Court has managed to reduce the number of interim measures ${ }^{310}$ and makes increasing use of the significant disadvantage rule. ${ }^{311}$ In short, the Court's efficiency has improved in various respects since the adoption of the Interlaken Declaration. These reforms fall into the first category of reform measures mentioned in Section 1. They do not challenge the Convention system's object and purpose, but change the functioning of the system. The downside of this development is that, even though the States have reaffirmed that the right to individual petition is a cornerstone of the Convention system, ${ }^{312}$ the system has become less accessible for applicants in some ways. ${ }^{313}$ The entry into force of Protocol 15 will reinforce this development. However, other measures have contributed to efficiency without decreasing accessibility, which is good news for applicants even though the caseload problem remains. ${ }^{314}$

The other background factor that this article discussed was opposition to the Court. $^{315}$ The most tangible fruit of this factor is the upcoming inclusion of a reference to subsidiarity and the margin of appreciation in the preamble to the Convention. ${ }^{316}$ Although this is a concrete change, it will most probably be of mainly symbolic importance for two reasons. First, the Court opposed the amendment and only the Court can ensure that the amendment is more than just symbolic. Second, reference to the Court's case law in the amendment means that the amendment can be interpreted as instructing the Court not to change anything at all. ${ }^{317}$ Less visible, but probably of greater practical relevance to the Court's interpretation of the Convention, is that the literature confirms cautiously that the Court has placed greater emphasis on the subsidiarity principle. ${ }^{318}$ Although various authors agree that this change has taken place at least in part as a reaction to the concerns uttered by the States in the declarations, this change is neither widespread nor necessarily leads to more deference to domestic authorities. ${ }^{319}$ Reduction in the number of interim measures and future amendment of the significant disadvantage criterion can also be seen as measures that strengthen respect for the subsidiarity principle. ${ }^{320}$ All in all, one can conclude that the States gained some of what they wanted, but also that these gains have led to little actual change and do not fundamentally alter the system's object and purpose.

This trend is also due to other factors and partially precedes the declarations, see Glas, supra $\mathrm{n} 7$. Section 2.A.

Ibid.

Section 3.D.ii.

Section 3.D.ii.

Section 3.D.i.

Ibid. 
A major innovation that resulted from the declarations is that the States can now permit their highest domestic courts to request an advisory opinion of the Court. ${ }^{321}$ This is a truly new procedure that is also supposed to increase respect for the subsidiarity principle. Since notions of dialogue and subsidiarity are not new to the Convention system, this innovation leaves intact the system's object and purpose. Other changes in the sphere of dialogue are that the Registrar is now obliged to inform the States of any proposal to amend the Rules of Court which concern proceedings and to invite them to comment ${ }^{322}$ and the establishment of the Superior Courts Network. ${ }^{323}$ Apart from these measures relating to dialogue, the remaining reforms are the codification of the pilot judgment procedure, ${ }^{324}$ the upcoming deletion of the right to object to relinquishment ${ }^{325}$ and the giving of reasons by single judges. ${ }^{326}$

\section{Final Observations}

Section 2.B has already suggested that the declarations did not contain proposals which would fundamentally change the Convention system's object and purpose. ${ }^{327}$ Section 4.B confirms that the implemented proposals have not led to any revolutionary changes which would fall into the second category of reform measures discussed in Section 1. Additionally, it can be concluded that the proposals have not always led to much actual change, although measures regarding caseload have had a great impact on the Court's functioning. Moreover, the examination of the proposals and what has become of them in Section 3 has led to the conclusion in this section that more than half the proposals have not been implemented, mainly due to the opposition of the Court. Therefore, it is unlikely, at least in the light of the declarations and their follow-up, that the States and the Court are prepared to take any 'more profound measures' if this is necessary according to the Committee's evaluation in 2019. ${ }^{328}$

The foregoing does not preclude the declarations from being of significance in the sense that they offer political support to the Court and the reforms that it has realised or intends to carry out, ${ }^{329}$ as President Costa also suggested. ${ }^{330}$ However, and probably unlike President Costa expected and hoped for, the organising State can also use a declaration, and in particular its draft, to express domestic opposition to the Court, ${ }^{331}$ although the adopted declarations are less critical and contain less farreaching proposals than their drafts. ${ }^{332}$ The fact that the declarations are also a means

326 Introduction to Section 3.F.

327 Section 2.B.

328 Section 1.

329 See, for example, the recurring elements in Section 2.B. Furthermore, the States regularly welcome the concrete steps of the Court. As mentioned, they welcomed, for example, the reasoning by Single Judges and the Superior Courts Network, see the introductions to Sections 3.3 and 3.F. They also welcomed the Court's follow-up to proposals in previous declarations: see Section 3.C.ii; Section 3.D.i; Section 3.D.vi; and Section 3.E.ii.

330 Section 2.A.

331 Section 2.B.

332 Ibid. 
to voice discontent with the Court or to criticise a specific approach of the Court may help to explain why so many proposals were included even though the Court opposed them and did not implement them. Irrespective of the Court's reaction, the States could signal their point of view to the Court by making proposals despite the chances of their rejection by the Court.

\section{ACKNOWLEDGMENTS}

The author would like to thank Dr Krommendijk for his valuable comments on an earlier draft of this article. 